\title{
ANALISIS KEMAMPUAN LITERASI STATISTIS DALAM MATERI VARIABILITAS
}

\author{
Iyam Maryati ${ }^{1 *}$ \\ ${ }^{1}$ Program Studi Pendidikan Matematika, Instituut Pendidikan Indonesia Garut, Indonesia \\ *iyammaryati@institutpendidikan .ac.id
}

Diterima: 03 Juni 2021. Disetujui: 22 Juni 2021. Dipublikasikan: 31 Juli 2021

\begin{abstract}
ABSTRAK
Artikel ini memuat penelitian mengenai kemampuan literasi statistis dalam materi variabilitas. Tujuan dari penelitian ini untuk mendeskripsikan kemampuan literasi statistis dalam materi variabilitas baik secara umum ditinjau dari hasil akhir kemampuan literasi statistis mahasiswa maupun secara khusus ditinjau dari setiap indikator dengan tiga kategori kemampuan literasi statistis mahasiswa yaitu tinggi, sedang, dan rendah. Subyek penelitian melibatkan 67 orang mahasiswa calon guru pendidikan matematika. metode yang digunakan dalam penelitian ini yaitu studi kualitatif secara deskriptif. Teknik pengumpulan data dilakukan dengan instrumen tes uraian dan wawancara. Tehnik analisis data dengan tehnik Miles and Hubberman. Hasil penelitian menunjukkan kemampuan literasi statistis mahasiswa pada kategori tinggi mampu menyelesaikan semua permasalahan yang disajikan dengan memahami data, menginterprestasikan data, dan mengkomunikasikan data dengan tepat. Mahasiswa kategori sedang menunjukkan kemampuan literasi statistis dalam indikator memahami data hanya terdapat pada soal nomor 1 , menginterprestasikan data mengkomunikasikan data sudah dapat melakukannya dengan tepat. Sedangkan untuk mahasiswa kategori kemampuan rendah masih belum mampu memahami data, menginterprestasikan data, dan mengkomunikasikan data sehingga banyak melakukan kesalahan. Peneliti menyarankan agar penelitian selanjutnya memperhatikan model pembelajaran dalam perkuliahan statistika deskriptif untuk meningkatkan kemampuan literasi statistis.
\end{abstract}

Kata kunci: Kemampuan Literasi Statistis, Variabilitas

\begin{abstract}
This article contains research on statistical literacy skills in material variability. The purpose of this study was to describe statistical literacy skills in material variability, both in general in terms of the final results of students' statistical literacy abilities and specifically in terms of each indicator with three categories of students' statistical literacy abilities, namely high, medium, and low. The research subjects involved 67 mathematics education teacher candidates. The method used in this research is descriptive qualitative study. The data collection technique was carried out by means of test descriptions and interviews. Data analysis techniques using the Miles and Huberman technique. The results showed that students' statistical literacy skills in the high category were able to solve all the problems presented by understanding the data, interpreting the data, and communicating the data appropriately. Students in the medium category show statistical literacy skills in the indicators of understanding data only in question number 1, interpreting data communicating data can do it correctly. Meanwhile, students in the low ability category are still not able to understand data, interpret data, and communicate data so they make many mistakes. The researcher suggests that further research should pay attention to the learning model in descriptive statistics lectures to improve statistical literacy skills.
\end{abstract}

Keywords: Statistical Literacy Ability, Variability.

\section{Pendahuluan}

Keterampilan dasar dalam memahami data, mengolah data, membuat grafik dan tabel, representasi data, dan memahami perhitungan statistika dasar merupakan kemampuan literasi statistis (Gundlach et al., 2015; Sari, 2015; Murod et al., 2019). Selanjutnya (Sharma, 2017) menyatakan bahwa literasi statistis merupakan kemampuan untuk mendiskusikan atau mengkomunikasikan informasi statistik. Oleh karena itu kemampuan literasi statistis merupakan kemampuan seseorang untuk dapat memahami data, menginterprestasikan data, dan megkomunikasikan data berdasarkan informasi data statistik. 


\section{Range: Jurnal Pendidikan Matematika Vol. 3 No. 1 Tahun 2021 Iyam Maryati}

Kemampuan literasi statistis ini sangat penting bagi semua orang dalam menentukan keputusan berdasarkan informasi yang diperoleh, sehingga memiliki ketepatan dalam membuat sebuah kesimpulan. Kemampuan literasi ini harus dikembangkan sejak dini karena membutuhkan proses yang sangat lama (Pierce \& Chick, 2013). Kompetensi guru dalam meningkatkan kemampuan literasi statistis ini memberikan kontribusi yang sangat besar.

Tetapi fenomena yang terjadi, masih banyak siswa maupun mahasiswa yang masih memiliki kemampuan literasi statistis ini dalam kategori rendah. Hal ini sejalan dengan penelitian (Ruhyana, 2016; Maryati et al., 2019) yang menyatakan siswa Sekolah Menengah Pertama masih mengalami kesulitan dalam belajar penyajian data dalam bentuk diagram dan grafik. Pulungan \& Herosian (2019) menyatakan dengan masih rendahnya kemampuan literasi statistis siswa Sekolah Menengah Atas dikembangkannya tes literasi statistis melalui tiga tahap pengembangan dan enam aspek literasi statistis. Begitu pula dengan kemampuan literasi statistis mahasiswa masih rendah sejalan dengan penelitian (Hafiyusholeh et al., 2017). Terdapat $37,5 \%$ dari 32 orang mahasiswa calon guru pendidikan agama islam yang mampu memberikan interprestasi data (Nahdi et al., 2021).

Penelitian ini menganalisis kemampuan literasi statistis dengan melibatkan subyek penelitian mahasiswa calon guru pendidikan matematika. Karena kemampuan literasi statistis siswa dapat berkembang apabila kompetensi yang dimiliki guru sangat berkualitas (Bhakti \& Maryani, 2017). Kemudian materi yang dipilih untuk dijadikan objek penelitian yaitu materi variabilitas. Karena materi ini merupakan pengetahuan dasar dalam mendeskripsikan ukuran pemusatan dan penyebaran data (Carlson \& Winquist, 2011).

Berdasarkan uraian di atas, tujuan dari penelitian ini adalah untuk mendeskripsikan kemampuan literasi statistis mahasiswa calon guru matematika dalam materi variabilitas. Adapun indikator-indikator kemampuan literasi statistis yang diteliti yaitu kemampuan memahami data, menginterprestasikan data, dan mengkomunikasikan data.

\section{Metode Penelitian}

Penelitian ini merupakan penelitian kualitatif dengan pendekatan deskriptif, yaitu penelitian yang mendeskripsikan, mengeksplorasi dan mengklarifikasi suatu fenomena, dengan mendeskripsikan variabel yang diukur (Gall, Borg, \& Gall, 1996). Subyek penelitian ini merupakan studi kasus yang melibatkan 67 orang mahasiswa calon guru pendidikan matematika yang mengikuti perkuliahan statistika deskriptif tahun akademik 2020/2021 pada salah satu perguruan tinggi swasta di kabupaten Garut.

Instrumen penelitian berupa tes uraian yang disusun berdasarkan indikator kemampuan literasi statistis. Indikator tersebut merupakan elemen pengetahuan yang diadopsi dari model (Gal, 2004). Adapun deskripsi indikator kemampuan literasi statistis dan rubrik skor yang digunakan dalam penelitian ini ditunjukkan dalam tabel 1. dan tabel 2. sebagai berikut.

Tabel 1. Deskripsi Indikator Kemampuan Literasi Statistis

\begin{tabular}{ll}
\hline \multicolumn{1}{c}{ Indikator } & \multicolumn{1}{c}{ Deskripsi } \\
\hline \multirow{3}{*}{ Memahami Data } & $\begin{array}{l}\text { Subyek mampu mengetahui informasi yang disajikan dalam soal, } \\
\text { mampu menentukan jenis data dalam soal sehingga dapat } \\
\text { menentukan langkah-langkah selanjutnya. }\end{array}$ \\
\hline \multirow{3}{*}{ Menginterprestasi Data } & $\begin{array}{l}\text { Subyek mampu menafsirkan informasi atau data yang diperoleh } \\
\text { dari proses pengolahan data sehingga mampu memberikan } \\
\text { keputusan yang tepat. }\end{array}$ \\
\hline \multirow{3}{*}{ Mengkomunikasikan Data } & $\begin{array}{l}\text { Subyek mampu menyajikan kembali dari proses pengolahan data } \\
\text { baik dalam bentuk grafik, diagram, tabel, atau kurva. Subyek } \\
\text { mampu memberikan penjelasan dalam menyimpulkan terhadap } \\
\text { keputusan yang diambil dalam penyelesaian permsalahan. }\end{array}$ \\
\hline
\end{tabular}

Tabel 2. Pedoman Penskoran kemampuan Literasi Statistis 


\section{Range: Jurnal Pendidikan Matematika Vol. 3 No. 1 Tahun 2021 Iyam Maryati}

\begin{tabular}{|c|c|}
\hline Indikator yang Diukur & Respon Siswa Terhadap Soal \\
\hline \multirow{5}{*}{ Memahami Data } & Tidak memberikan jawaban \\
\hline & Tidak mampu memahami informasi atau data \\
\hline & $\begin{array}{l}\text { Mampu memahami informasi atau data tetapi terdapat } \\
\text { banyak kesalahan. }\end{array}$ \\
\hline & $\begin{array}{l}\text { Mampu memahami informasi atau data tetapi terdapat } \\
\text { sedikit kesalahan. }\end{array}$ \\
\hline & Mampu memahami informasi atau data secara tepat. \\
\hline \multirow{5}{*}{ Menginterprestasikan Data } & Tidak memberikan jawaban \\
\hline & $\begin{array}{l}\text { Tidak mampu menginterprestasikan proses pengolahan } \\
\text { data. }\end{array}$ \\
\hline & $\begin{array}{l}\text { Mampu menginterprestasikan proses pengolahan data } \\
\text { tetapi terdapat banyak kesalahan. }\end{array}$ \\
\hline & $\begin{array}{l}\text { Mampu menginterprestasikan proses pengolahan data } \\
\text { tetapi terdapat sedikit kesalahan. }\end{array}$ \\
\hline & $\begin{array}{l}\text { Mampu menginterprestasikan proses pengolahan data } \\
\text { secara tepat. }\end{array}$ \\
\hline \multirow{5}{*}{ Mengkonunikasikan Data } & Tidak memberikan jawaban \\
\hline & $\begin{array}{l}\text { Tidak mampu mengkomunikasikan hasil dari pengolahan } \\
\text { informasi atau data. }\end{array}$ \\
\hline & $\begin{array}{l}\text { Mampu mengkomunikasikan hasil dari pengolahan } \\
\text { informasi atau data tetapi terdapat banyak kesalahan. }\end{array}$ \\
\hline & $\begin{array}{l}\text { Mampu mengkomunikasikan hasil dari pengolahan } \\
\text { informasi atau data tetapi terdapat sedikit kesalahan. }\end{array}$ \\
\hline & $\begin{array}{l}\text { Mampu mengkomunikasikan hasil dari pengolahan } \\
\text { informasi atau data secara tepat. }\end{array}$ \\
\hline
\end{tabular}

Pengumpulan data dilakukan melalui tes uraian yang terdiri dari 3 butir soal. Pada soal nomor 1 diberikan beberapa data nilai mahasiswa dalam mata kuliah statistika deskriptif, pada soal nomor 1 ini mahasiswa menentukan distribusi nilai dengan ukuran kuartil. Pada soal nomor 2, terdapat data dari hasil ujian mata kuliah statistika inferensial mahasiswa program studi pendidikan matematika semester IV tahun akademik 2019/2020, pada soal nomor 2 ini mahasiswa menentukan rata-rata, standar deviasi, angka standar untuk rata-rata, peringkat nilai (A, B, C, D, dan E) berdasar angka standar, menentukan jumlah mahasiswa pada masing-masing peringkat nilai, dan menentukan jumlah mahasiswa yang tidak lulus. Adapun soal nomor 3, mahasiswa menentukan nilai suatu mata kuliah mana yang lebih baik dilihat dari rata-rata dan simpangan bakunya. Soal tes kemampuan literasi statistis dalam materi variabilitas ditunjukkan dalam gambar 1 berikut.

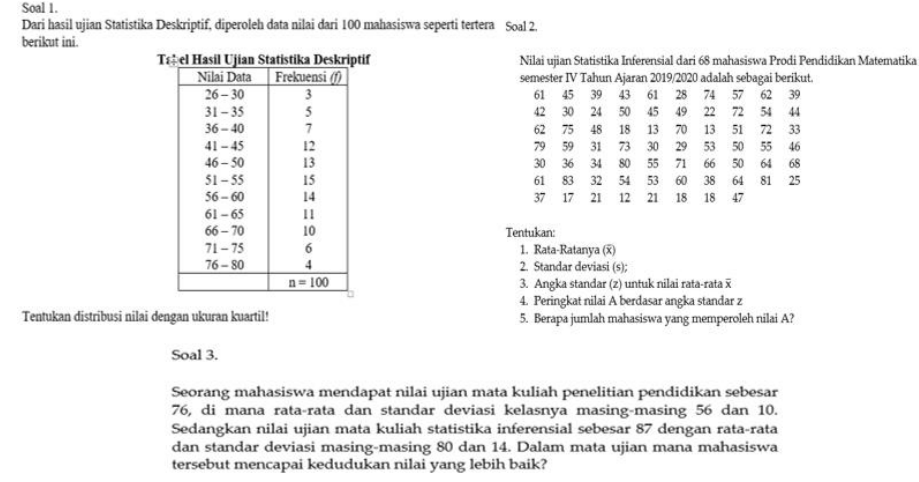




\section{Range: Jurnal Pendidikan Matematika Vol. 3 No. 1 Tahun 2021 Iyam Maryati}

\section{Gambar 1. Tes Kemampuan Literasi Statistis}

Setelah memperoleh hasil uji literasi statistis dilakukan pengkategorian kemampuan literasi statistis dengan tiga kategori yaitu tinggi, sedang, dan rendah. Pengkategorian menggunakan norma kategori (Azwar, 2012). Wawancara dilakukan dengan subyek penelitian untuk mengkonfirmasi mengenai jawaban yang telah ditulis, dengan menggunakan panduan wawancara terstruktur untuk menyelidiki kemampuan literasi statistis. Adapun analisis data dengan proses analisis data yang mengacu pada langkah-langkah reduksi data, penyajian data, dan penarikan kesimpulan (Miles \& Huberman, 1994).

\section{Hasil Penelitian dan Pembahasan}

Hasil dari tes soal kemampuan literasi statistis dalam penelitian ini diperoleh nilai rata-rata sebesar 1,81, simpangan baku sebesar 0,37, nilai tertinggi 2,5, dan nilai terrendah 0,75 dari skala penilaian interval 1 sampai 4 . Setelah dilakukan pengkategorian tedapat tiga kategori yaitu sebanyak 13 orang mahasiswa termasuk kategori tinggi, 46 orang mahasiswa termasuk kategori sedang, dan 8 orang mahasiswa termasuk kategori rendah. Dari subyek penelitian dipilih masing-masing satu orang mahasiswa untuk mewakili setiap kategori kemampuan. Hasil dari analisis pekerjaan mahasiswa dari setiap kategori kemampuan ditunjukkan dalam gambar. Berikut ini hasil kemampuan literasi statistis mahasiswa ditinjau dari masing-masing indikator.

a. Kategori Mahasiswa Berkemampuan Tinggi

Mahasiswa yang memiliki kemampuan literasi statistis tinggi terdapat 13 orang mahasiswa. Sebagian besar mahasiswa mampu memahami data, menginterprestasikan data, dan mengkomunikasikan data dengan tepat. Berikut ini deskripsi hasil kemampuan literasi statistis kategori mahasiswa berkemampuan tinggi.

Tabel 3. Deskripsi Hasil Kategori Mahasiswa Berkemampuan Tinggi

\begin{tabular}{|c|c|c|c|c|}
\hline Indikator yang Diukur & Respon Siswa Terhadap Soal & Skor & $\begin{array}{c}\text { Jumlah } \\
\text { mahasiswa }\end{array}$ & $\begin{array}{c}\text { Persentase } \\
(\%)\end{array}$ \\
\hline \multirow{5}{*}{ Memahami Data } & Tidak memberikan jawaban & 0 & 0 & 0,00 \\
\hline & $\begin{array}{l}\text { Tidak mampu memahami } \\
\text { informasi atau data }\end{array}$ & 1 & 0 & 0,00 \\
\hline & $\begin{array}{l}\text { Mampu memahami informasi atau } \\
\text { data tetapi terdapat banyak } \\
\text { kesalahan. }\end{array}$ & 2 & 0 & 0,00 \\
\hline & $\begin{array}{l}\text { Mampu memahami informasi atau } \\
\text { data tetapi terdapat sedikit } \\
\text { kesalahan. }\end{array}$ & 3 & 2 & 15,38 \\
\hline & $\begin{array}{l}\text { Mampu memahami informasi atau } \\
\text { data secara tepat. }\end{array}$ & 4 & 11 & 84,62 \\
\hline \multirow{5}{*}{$\begin{array}{c}\text { Menginterprestasikan } \\
\text { Data }\end{array}$} & Tidak memberikan jawaban & 0 & 0 & 0,00 \\
\hline & $\begin{array}{lr}\text { Tidak } & \text { mampu } \\
\text { menginterprestasikan } & \text { proses } \\
\text { pengolahan data. } & \\
\end{array}$ & 1 & 0 & 0,00 \\
\hline & $\begin{array}{l}\text { Mampu menginterprestasikan } \\
\text { proses pengolahan data tetapi } \\
\text { terdapat banyak kesalahan. }\end{array}$ & 2 & 0 & 0,00 \\
\hline & $\begin{array}{l}\text { Mampu menginterprestasikan } \\
\text { proses pengolahan data tetapi } \\
\text { terdapat sedikit kesalahan. }\end{array}$ & 3 & 3 & 23,08 \\
\hline & $\begin{array}{l}\text { Mampu menginterprestasikan } \\
\text { proses pengolahan data secara }\end{array}$ & 4 & 10 & 76,92 \\
\hline
\end{tabular}


Range: Jurnal Pendidikan Matematika Vol. 3 No. 1 Tahun 2021 Iyam Maryati

\begin{tabular}{|c|c|c|c|c|}
\hline Indikator yang Diukur & Respon Siswa Terhadap Soal & Skor & $\begin{array}{c}\text { Jumlah } \\
\text { mahasiswa }\end{array}$ & $\begin{array}{c}\text { Persentase } \\
(\%)\end{array}$ \\
\hline & tepat. & & & \\
\hline \multirow{5}{*}{ Mengkonunikasikan Data } & Tidak memberikan jawaban & 0 & 0 & 0,00 \\
\hline & $\begin{array}{l}\text { Tidak mampu mengkomunikasikan } \\
\text { hasil dari pengolahan informasi } \\
\text { atau data. }\end{array}$ & 1 & 0 & 0,00 \\
\hline & $\begin{array}{l}\text { Mampu mengkomunikasikan hasil } \\
\text { dari pengolahan informasi atau } \\
\text { data tetapi terdapat banyak } \\
\text { kesalahan. }\end{array}$ & 2 & 0 & 0,00 \\
\hline & $\begin{array}{l}\text { Mampu mengkomunikasikan hasil } \\
\text { dari pengolahan informasi atau } \\
\text { data tetapi terdapat sedikit } \\
\text { kesalahan. }\end{array}$ & 3 & 4 & 30,77 \\
\hline & $\begin{array}{l}\text { Mampu mengkomunikasikan hasil } \\
\text { dari pengolahan informasi atau } \\
\text { data secara tepat. }\end{array}$ & 4 & 9 & 69,23 \\
\hline
\end{tabular}

Berdasarkan tabel 3. di atas menunjukkan kemampuan mahasiswa dalam memahami data terdapat sebanyak 2 orang atau sebesar 5,38 persen mampu memahami informasi atau data yang disajikan tetapi terdapat sedikit kesalahan. Dan sebanyak 11 orang mahasiswa atau sebesar 84,62 persen mahasiswa mampu memahami informasi atau data secara tepat.

Respon mahasiswa terhadap soal dalam indikator menginterprestasikan data terdapat sebanyak 3 orang mahasiswa atau sebesar 23,08 persen mahasiswa yang mampu menafsirkan proses pengolahan data dengan dengan sedikit melakukan kesalahan. Dan sebanyak 10 orang mahasiswa atau sebesar 76,92 persen mahasiswa yang mampu menafsirkan proses pengolahan data secara tepat.

Respon mahasiswa terhadap soal dalam indikator mengkomunikasikan data terdapat sebanyak 4 orang mahasiswa atau sebesar 30,77 persen mahasiswa yang mampu mengkomunikasikan hasil dari pengolahan data dengan dengan sedikit melakukan kesalahan. Dan sebanyak 9 orang mahasiswa atau sebesar 69,23 persen mahasiswa yang mampu mengkomunikasikan hasil dari pengolahan data secara tepat.

Berikut sampel jawaban mahasiswa kategori kemampuan tinggi dalam menyelesaikan tes kemampuan literasi statistis yang diberikan dapat dilihat pada gambar 1. sebagai berikut.

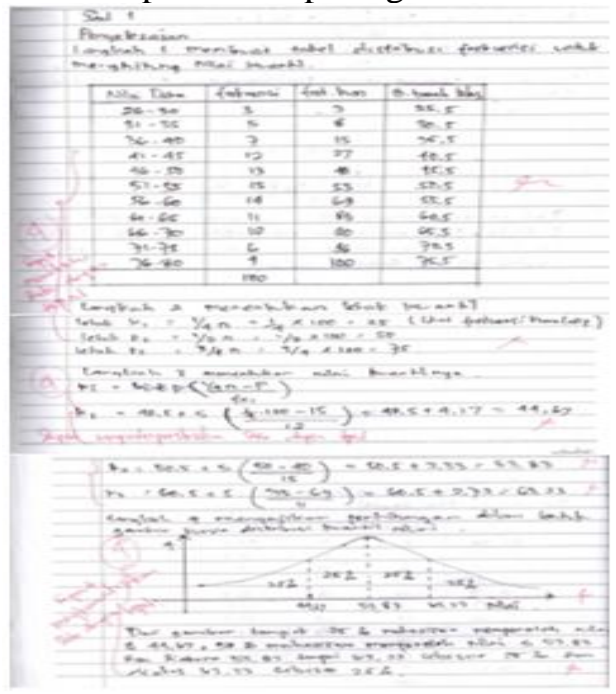

Gambar 1. Jawaban Mahasiswa Kategori Kemampuan Tinggi 


\section{Range: Jurnal Pendidikan Matematika Vol. 3 No. 1 Tahun 2021 Iyam Maryati}

Gambar 1. di atas merupakan jawaban mahasiswa kategori kemampuan tinggi dalam menyelesaikan soal kemampuan literasi statistis. Pada semua nomor soal yang diberikan mahasiswa mampu memahami data, menginterprestasikan data, dan mengkomunikasikan data dengan tepat.

b. Kategori Mahasiswa Berkemampuan Sedang

Mahasiswa yang memiliki kemampuan literasi statistis sedang terdapat 47 orang mahasiswa. Hampir sebagian besar mahasiswa mampu memahami data, menginterprestasikan data, dan mengkomunikasikan data dengan tepat. Berikut ini deskripsi hasil kemampuan literasi statistis kategori mahasiswa berkemampuan sedang.

Tabel 4. Deskripsi Hasil Kategori Mahasiswa Berkemampuan Sedang

\begin{tabular}{|c|c|c|c|c|}
\hline Indikator yang Diukur & Respon Siswa Terhadap Soal & Skor & $\begin{array}{c}\text { Jumlah } \\
\text { mahasiswa }\end{array}$ & $\begin{array}{c}\text { Persentase } \\
(\%)\end{array}$ \\
\hline \multirow{5}{*}{ Memahami Data } & Tidak memberikan jawaban & 0 & 0 & 0,00 \\
\hline & $\begin{array}{ll}\text { Tidak mampu memahami } \\
\text { informasi atau data }\end{array}$ & 1 & 0 & 0,00 \\
\hline & $\begin{array}{l}\text { Mampu memahami informasi atau } \\
\text { data tetapi terdapat banyak } \\
\text { kesalahan. }\end{array}$ & 2 & 5 & 10,64 \\
\hline & $\begin{array}{l}\text { Mampu memahami informasi atau } \\
\text { data tetapi terdapat sedikit } \\
\text { kesalahan. }\end{array}$ & 3 & 12 & 25,53 \\
\hline & $\begin{array}{l}\text { Mampu memahami informasi atau } \\
\text { data secara tepat. }\end{array}$ & 4 & 30 & 63,83 \\
\hline \multirow{5}{*}{$\begin{array}{l}\text { Menginterprestasikan } \\
\text { Data }\end{array}$} & Tidak memberikan jawaban & 0 & 0 & 0,00 \\
\hline & $\begin{array}{lr}\text { Tidak } & \text { mampu } \\
\text { menginterprestasikan } & \text { proses } \\
\text { pengolahan data. } & \\
\end{array}$ & 1 & 0 & 0,00 \\
\hline & $\begin{array}{l}\text { Mampu menginterprestasikan } \\
\text { proses pengolahan data tetapi } \\
\text { terdapat banyak kesalahan. }\end{array}$ & 2 & 7 & 14,89 \\
\hline & $\begin{array}{l}\text { Mampu menginterprestasikan } \\
\text { proses pengolahan data tetapi } \\
\text { terdapat sedikit kesalahan. }\end{array}$ & 3 & 19 & 40,43 \\
\hline & $\begin{array}{l}\text { Mampu menginterprestasikan } \\
\text { proses pengolahan data secara } \\
\text { tepat. }\end{array}$ & 4 & 21 & 44,68 \\
\hline \multirow{5}{*}{ Mengkonunikasikan Data } & Tidak memberikan jawaban & 0 & 0 & 0,00 \\
\hline & $\begin{array}{l}\text { Tidak mampu mengkomunikasikan } \\
\text { hasil dari pengolahan informasi } \\
\text { atau data. }\end{array}$ & 1 & 0 & 0,00 \\
\hline & $\begin{array}{l}\text { Mampu mengkomunikasikan hasil } \\
\text { dari pengolahan informasi atau } \\
\text { data tetapi terdapat banyak } \\
\text { kesalahan. }\end{array}$ & 2 & 10 & 21,28 \\
\hline & $\begin{array}{l}\text { Mampu mengkomunikasikan hasil } \\
\text { dari pengolahan informasi atau } \\
\text { data tetapi terdapat sedikit } \\
\text { kesalahan. }\end{array}$ & 3 & 22 & 46,81 \\
\hline & $\begin{array}{l}\text { Mampu mengkomunikasikan hasil } \\
\text { dari pengolahan informasi atau }\end{array}$ & 4 & 15 & 31,91 \\
\hline
\end{tabular}




\begin{tabular}{|c|c|c|c|c|}
\hline Indikator yang Diukur & Respon Siswa Terhadap Soal & Skor & $\begin{array}{c}\text { Jumlah } \\
\text { mahasiswa }\end{array}$ & $\begin{array}{c}\text { Persentase } \\
(\%)\end{array}$ \\
\hline
\end{tabular}

Berdasarkan tabel 4. di atas menunjukkan kemampuan mahasiswa dalam memahami data terdapat sebanyak 5 orang atau sebesar 10,64 persen mampu memahami informasi atau data yang disajikan tetapi masih terdapat banyak kesalahan. Sebanyak 12 orang atau sebesar 25,53 persen mampu memahami informasi atau data yang disajikan tetapi terdapat sedikit kesalahan Dan sebanyak 30 orang mahasiswa atau sebesar 63,83 persen mahasiswa mampu memahami informasi atau data secara tepat.

Respon mahasiswa terhadap soal dalam indikator menginterprestasikan data terdapat sebanyak 7 orang mahasiswa atau sebesar 14,89 persen mahasiswa yang mampu menafsirkan proses pengolahan data tetapi masih banyak melakukan kesalahan. sebanyak 19 orang mahasiswa atau sebesar 40,43 persen mahasiswa yang mampu menafsirkan proses pengolahan data dengan sedikit melakukan kesalahan. Dan sebanyak 21 orang mahasiswa atau sebesar 44,68 persen mahasiswa yang mampu menafsirkan proses pengolahan data secara tepat.

Respon mahasiswa terhadap soal dalam indikator mengkomunikasikan data terdapat sebanyak 10 orang mahasiswa atau sebesar 21,28 persen mahasiswa yang mampu mengkomunikasikan hasil dari pengolahan data tetapi masih banyak melakukan kesalahan. Sebanyak 22 orang mahasiswa atau sebesar 46,81 persen mahasiswa yang mampu mengkomunikasikan hasil dari pengolahan data dengan sedikit melakukan kesalahan. Dan sebanyak 15 orang mahasiswa atau sebesar 31,91 persen mahasiswa yang mampu mengkomunikasikan hasil dari pengolahan data secara tepat.

Adapun hasil pekerjaan dalam penyelesaian soal kemampuan literasi statistis mahasiswa kaegori kemampuan sedang ditunjukkan dalam gambar 2. Berikut ini.

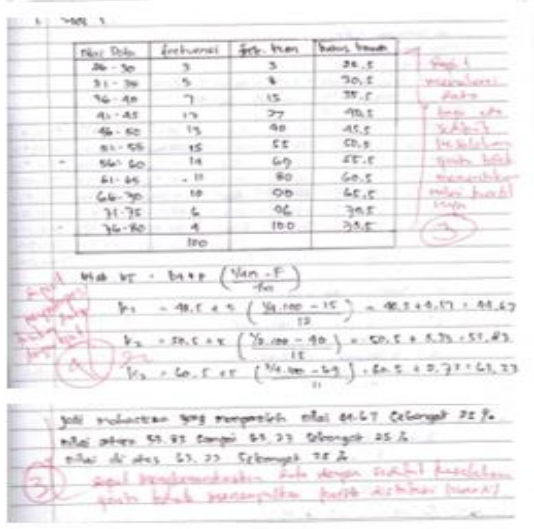

Gambar 2. Jawaban Mahasiswa Kemampuan Sedang

Berdasarkan gambar 2. di atas kemampuan literasi statistis mahasiswa kemampuan sedang dalam menyelesaikan permasalahan. Pada soal nomor 1 mahasiswa mampu memahami data tetapi terdapat sedikit kesalahan, mampu menginterprestasikan data dengan tepat, dan juga mengkomunikasikan data dengan sedikit kesalahan. Pada soal nomor 2 mahasiswa mampu memahami data dengan tepat tetapi dalam menginterprestasikan data dan mengkomunikasikan data dengan sedikit kesalahan. Sedangkan pada soal nomor 3 mahasiswa mampu memahami data dan menginterprestasikan data dengan tepat tetapi dalam mengkomunikasikan data masih terdapat sedikit kesalahan.

c. Kategori Mahasiswa Berkemampuan Rendah

Mahasiswa yang memiliki kemampuan literasi statistis sedang terdapat 7 orang mahasiswa. Hampir sebagian besar mahasiswa belum mampu memahami data, menginterprestasikan data, dan mengkomunikasikan data dengan tepat. Berikut ini deskripsi hasil kemampuan literasi statistis kategori mahasiswa berkemampuan rendah.

Tabel 5. Deskripsi Hasil Kategori Mahasiswa Berkemampuan Rendah

\begin{tabular}{|c|c|c|c|c|}
\hline Indikator yang Diukur & Respon Siswa Terhadap Soal & Skor & $\begin{array}{c}\text { Jumlah } \\
\text { mahasiswa }\end{array}$ & $\begin{array}{c}\text { Persentase } \\
(\%)\end{array}$ \\
\hline
\end{tabular}




\section{Range: Jurnal Pendidikan Matematika Vol. 3 No. 1 Tahun 2021 Iyam Maryati}

\begin{tabular}{|c|c|c|c|c|}
\hline Indikator yang Diukur & Respon Siswa Terhadap Soal & Skor & $\begin{array}{c}\text { Jumlah } \\
\text { mahasiswa }\end{array}$ & $\begin{array}{l}\text { Persentase } \\
(\%)\end{array}$ \\
\hline \multirow{6}{*}{ Memahami Data } & Tidak memberikan jawaban & & 3 & 42 \\
\hline & & & & ,86 \\
\hline & $\begin{array}{l}\text { Tidak mampu memahami } \\
\text { informasi atau data }\end{array}$ & & 4 & ,14 \\
\hline & $\begin{array}{l}\text { Mampu memahami informasi atau } \\
\text { data tetapi terdapat banyak } \\
\text { kesalahan. }\end{array}$ & 2 & 0 & 00,00 \\
\hline & $\begin{array}{l}\text { Mampu memahami informasi atau } \\
\text { data tetapi terdapat sedikit } \\
\text { kesalahan. }\end{array}$ & 3 & 0 & 00,00 \\
\hline & $\begin{array}{l}\text { Mampu memahami informasi atau } \\
\text { data secara tepat. }\end{array}$ & 4 & 0 & 00,00 \\
\hline \multirow{5}{*}{$\begin{array}{l}\text { Menginterprestasikan } \\
\text { Data }\end{array}$} & Tidak memberikan jawaban & 0 & 5 & 71,43 \\
\hline & $\begin{array}{lr}\text { Tidak } & \text { mampu } \\
\text { menginterprestasikan } & \text { proses } \\
\text { pengolahan data. } & \\
\end{array}$ & 1 & 2 & 28,57 \\
\hline & $\begin{array}{l}\text { Mampu menginterprestasikan } \\
\text { proses pengolahan data tetapi } \\
\text { terdapat banyak kesalahan. }\end{array}$ & 2 & 0 & 0,00 \\
\hline & $\begin{array}{l}\text { Mampu menginterprestasikan } \\
\text { proses pengolahan data tetapi } \\
\text { terdapat sedikit kesalahan. }\end{array}$ & 3 & 0 & 00,00 \\
\hline & $\begin{array}{l}\text { Mampu menginterprestasikan } \\
\text { proses pengolahan data secara } \\
\text { tepat. }\end{array}$ & 4 & 0 & 00,00 \\
\hline \multirow{5}{*}{ Mengkonunikasikan Data } & Tidak memberikan jawaban & 0 & 5 & 71,43 \\
\hline & $\begin{array}{l}\text { Tidak mampu mengkomunikasikan } \\
\text { hasil dari pengolahan informasi } \\
\text { atau data. }\end{array}$ & 1 & 2 & 28,57 \\
\hline & $\begin{array}{l}\text { Mampu mengkomunikasikan hasil } \\
\text { dari pengolahan informasi atau } \\
\text { data tetapi terdapat banyak } \\
\text { kesalahan. }\end{array}$ & 2 & 0 & 0,00 \\
\hline & $\begin{array}{l}\text { Mampu mengkomunikasikan hasil } \\
\text { dari pengolahan informasi atau } \\
\text { data tetapi terdapat sedikit } \\
\text { kesalahan. }\end{array}$ & 3 & 0 & 00,00 \\
\hline & $\begin{array}{l}\text { Mampu mengkomunikasikan hasil } \\
\text { dari pengolahan informasi atau } \\
\text { data secara tepat. }\end{array}$ & 4 & 0 & 00,00 \\
\hline
\end{tabular}

Berdasarkan tabel 5. di atas menunjukkan kemampuan mahasiswa dalam memahami data terdapat sebanyak 3 orang atau sebesar 42,86 persen tidak memberikan jawaban dan sebanyak 4 orang mahasiswa tidak mampu memahami informasi atau data yang disajikan. Respon mahasiswa terhadap soal dalam indikator menginterprestasikan data dan mengkomunikasikan data terdapat sebanyak 5 orang mahasiswa atau sebesar 71,43 persen mahasiswa yang tidak memberikan jawaban, sebanyak 2 orang mahasiswa atau sebesar 28,57 persen mahasiswa yang tidak mampu menginterprestasikan proses pengolahan data dan juga tidak mampu mengkomunikasikan hasil dari pengolahan data. 


\section{Range: Jurnal Pendidikan Matematika Vol. 3 No. 1 Tahun 2021 Iyam Maryati}

Kemampuan mahasiswa kategori rendah dalam menyelesaikan permasalahan dalam literasi statistis ditunjukkan oleh gambar 3. berikut ini.

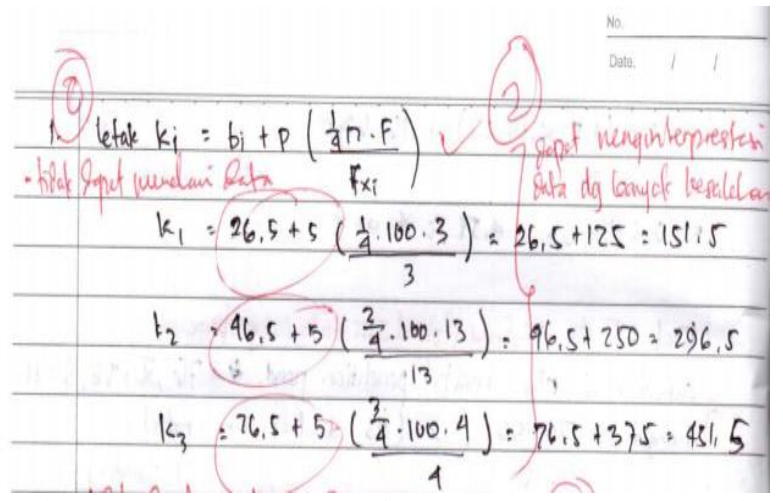

Gambar 3. Jawaban Mahasiswa Kemampuan Rendah

Berdasarkan gambar 3. di atas mahasiswa kategori kemampuan rendah dalam menyelesaikan permasalahan literasi statistis menunjukkan pada soal nomor 1 tidak dapat memahami data dan mengkomunikasikan data dengan tidak memberikan jawaban, dapat menginterprestasikan data tetapi banyak kesalahan. Pada soal nomor 2 tidak mampu memahami data, menginterprestasikan data, dan mengkomunikasikan data dengan tidak memberikan jawaban. Sedangkan pada soal nomor 3 tidak dapat memahami data dengan tidak memberikan jawaban. Dapat menginterprestasikan dan mengkomunikasikan data tetapi masih banyak terdapat kesalahan.

\section{Pembahasan}

Berdasarkan hasil penelitian, kategori kemampuan mahasiswa ditinjau dari kemampuan literasi statistis secara umum dapat dibagi menjadi tiga kategori yaitu: tinggi, sedang, dan rendah. Sehingga pembagian kategori ini, peneliti dapat mendeskripsikan kemampuan literasi statistis mahasiswa secara detail. Kemampuan mahasiswa dapat diperhatikan dengan baik, dengan demikian peneliti berusaha semaksimal mungkin untuk memberikan pelayanan dalam pembelajaran. Sedangkan kemmapuan literasi statistis berdasarkan indikator-indikatornya yaitu memahami data, menginterprestasikan data, dan mengkomunikasikan data.

Pada kategori kemampuan tinggi mahasiswa sebagian besar dapat menyelesaikan permasalahan yang diberikan. Hal ini sejalan dengan pendapat (Croft, T., Kouvela, E., \& Martinez, 2018) yang menyatakan bahwa subyek yang memiliki kategori tinggi cenderung dapat memahami informasiinformasi yang disajikan dalam sebuah permasalahan. Pada soal nomor 1 kemampuan mahasiswa dalam memahami data sudah melakukannya dengan tepat. Mahasiswa mampu memahami data yang ada dalam permasalahan dengan membuat tabel distribusi frekuensi untuk menghitung nilai kuartil. Sehingga mahasiswa memahami frekuensi kumulatif dan batas bawah kelas dari data tersebut. Kemudian mahasiswa dapat menentukan letak kuartil pertama dengan memperhatikan rumus satu perempat dikalikan dengan banyaknya data, sehingga diperoleh letak kuarti pertama dua puluh lima dengan memperhatikan frekuensi kumulatif. Begitu pula dengan letak kuartil kedua dan ketiga dengan mengalikan setengah dan tiga perempat dengan jumlah banyaknya data. Dengan demikian letak kuartil kedua lima puluh dan letak kuartil ketiga tujuh puluh lima. Kemampuan mahasiswa dalam menginterprestasikan data mampu menentukan nilai kuartil dengan tepat. Dan mahasiswa juga mampu mengkomunikasikan data dengan tepat dalam menyajikan kembali hasil dari proses pengolahan data, sehingga kesimpulan yang diambil dapat dipahami denga tepat pula.

Pada soal nomor 2 mahasiswa kategori tinggi mampu memahami data dengan tepat yaitu dengan menentukan nilai tertinggi, nilai terrendah, rentang nilai, dan jumlah kelas interval yang membantu mahasiswa dalam melakukan perhitungan untuk penyelesaian permasalahan. Mahasiswa dapat menginterprestasikan data dengan tepat yaitu dengan melakukan perhitungan-perhitungan untuk menyelesaikan permasalahan yang diberikan berdasarkan pengetahuan statistis mereka. Sejalan dengan 


\section{Range: Jurnal Pendidikan Matematika Vol. 3 No. 1 Tahun 2021 Iyam Maryati}

penelitian (Hariyanti, 2020) yang menyatakan kemampuan dalam melakukan evaluasi informasi secara kritis dapat melibatkan perhitungan matematis dalam kemmapuan literasi statistis. Adapun penyelesaian permasalahannya yaitu menentukan rata-rata, menentukan standar deviasi, menentukan nilai standar untuk nilai rata-rata dengaan rumus angka standar, menentukan peringkat nilai $\mathrm{A}$, dan menentukan jumlah banyaknya mahasiswa yang memperoleh nilai A. Dengan kemampuan menginterprestasikan data dengan tepat, maka kemampuan mahasiswa dalam mengkomunikasikan data pun mampu memberikan kesimpulan dengan tepat pula. Oleh karena itu proses pengolahan data atau penginterprestasian yang tepat sangat menentukan kesimpulan dari hasil pengolahan data (Takaria \& Talakua, 2018b).

Pada soal nmor 3 mahasiswa kategori kemampuan tinggi mampu memahami data dengan tepat yaitu mampu mengidentifikasi data yang disajikan dalam permasalahan, sehingga memahami nilai ratarata, simpangan baku dan nilai $\mathrm{x}$. mahasiswa mampu melakukan interprestasi data denga tepat yaitu melakukan perhitungan dalam menentukan harga $\mathrm{z}$ dengan mengurangi nilai $\mathrm{x}$ oleh nlai rata-rata kemudian dibagi simpangan baku. Dengan demikian mahasiswa mampu mengkomunikasikan data dengan memberikan kesimpulan yang tepat yaitu posisi nilai penelitian pendidikan lebih baik daripada posisi nilai statistika inferensial. Pendapat yang diajukan pun berdasarkan proses dari pengolahan data yang tepat (Takaria \& Talakua, 2018a).

Mahasiswa dengan kategori kemampuan sedang secara umum hamper sebagian besar memiliki kemampuan literasi statistis yang baik. pada soal nomor 1 mahasiswa dapat memahami data tetapi terdapat sedikit kesalahan yaitu mahasiswa hanya membuat tabel frekuensi kumulatif tanpa menentukan nilai letak kuartilnya. Dalam mengintrprestasikan data mahasiswa sudah melakukannya dengan tepat yaitu mampu melakukan perhitungan nilai kuartil dengan benar berdasarkan pengetahuan statistisnya. Tetapi dalam menkomunikasikan data mahasiswa masih melakukan sedikit kesalahan yaitu tidak dapat menyajikan kembali hasil pengolahan data dalam bentuk kurva distribusi frekuensi (Khaerunnisa \& Pamungkas, 2017).

Pada soal nomor 2 mahasiswa mampu memahami data dengan tepat yaitu dapat menentukan nilai tertinggi, nilai terrendah, nilai rentang, dan panjang kelas interval dari data yang disajikan. Tetapi mahasiswa dalam menginterprestasikan data masih terdapat sedikit kesalahan yaitu dalam perhitungan tidak menuliskan kembali pengetahuan statistisnya yang berkaitan dengan rumus yang digunakan (Tiro, 2018). Begitu pula dalam mengkomunikasikan data mahasiswa melakukan sedikit kesalahan dengan tidak memberikan argument atas kesimpulan yang didasarkan kepada proses pengolahan data atau penginterprestasian data.

Mahasiswa dengan kategori sedang dalam penyelesaian permasalahan soal nomor 3 menunjukkan kemampuan memahami data dengan tepat yaitu mampu mengidentifikasi data atau informasi yang disajikan dalam permasalahan dengan tepat yaitu nilai $\mathrm{x}$, nilai rata-rata dan juga simpangan baku. Mahasiswa menginterprestasikan data dengan tepat yaitu dapat melakukan perhitungan dengan benar berdasarkan pengetahuan statistisnya (Maryati, 2019; S. Widodo et al., 2021). Dalam mengkomunikasikan data mahasiswa terdapat sedikit kesalahan yaitu mampu memberikan penjelasan terhadap kesimpulan akhir berdasarkan hasil pengolahan data.

Kategori kemampuan rendah menunjukkan sebagian besar mahasiswa belum memiliki kemampuan literasi statistis yang baik. hal ini dapt terlihat dari hasil pekerjaan mahasiswa pada soal nomor 1 mahasiswa belum mampu memahami data yaitu tidak dapat memberikan jawaban. Tetapi dalam menginterprestasikan data mahasiswa masih terdapat banyak kesalahan, yaitu melakukan perhitungan tidak didasarkan kepada pemahaman data yang baik, dan menghasilkan jawaban akhir yang keliru. Akibatnya dalam mengkomunikasikan data pun mahasiswa tidak dapat memberikan jawaban. Hal ini sejalan dengan penelitian (Ruhyana, 2016; Nilasari \& Anggreini, 2019) yang mengungkapkan siswa pada kategori rendah cenderung memiliki kesulitan dalam memahami informasi.

Pada soal nomor 2 mahasiswa kategori kemampuan rendah tidak dapat memahami data, menginterprestasikan data, dan mengkomunikasikan data, hal ini ditunjukkan dengan tidak memberikan jawaban dalam penyelesaian permasalahan. Sedangkan dalam soal nomr 3 mahasiswa tidak dapat memahami data dengan tidak memberikan jawaban, dalam menginterprestasikan data mahasiswa 


\section{Range: Jurnal Pendidikan Matematika Vol. 3 No. 1 Tahun 2021 Iyam Maryati}

melakukan banyak kesalahan yaitu melakukan penghitungan dengan rumus yang keliru sehingga menyebabkan hasilnya keliru juga (Nahdi et al., 2021; Annizar et al., 2020). Mahasiswa mengkomunikasikan data dengan melakukan banyak kesalahan yaitu memberikan keputusan terhadap kesimpulan yang diambil tidak berdasarkan hasil pengolahan data.

\section{Kesimpulan}

Berdasarkan hasil dan pembahasan, penelitian ini menyimpulkan bahwa kemampuan literasi statistis mahasiswa pada kategori tinggi mampu menyelesaikan semua permasalahan yang disajikan dengan memahami data, menginterprestasikan data, dan mengkomunikasikan data dengan tepat. Mahasiswa kategori sedang menunjukkan kemampuan literasi statistis dalam indikator memahami data hanya terdapat pada satu soal saja, menginterprestasikan data mengkomunikasikan data sudah dapat melakukannya dengan tepat. Sedangkan untuk mahasiswa kategori kemampuan rendah masih belum mampu memahami data, menginterprestasikan data, dan mengkomunikasikan data sehingga banyak melakukan kesalahan. Kontribusi dalam penelitian ini, memberikan gambaran atau deskripsi kemampuan literasi statistis mahasiswa dalam materi variabilitas. Dengan demikian keterbaruan dalam penelitian ini, mahasiswa dan dosen lebih memperhatikan kemampuan literasi statistis berdasarkan indikatorindikatornya. Dan memberikan masukan bagi peneliti sendiri maupun peneliti lainnya untuk menerapkan model pembelajaran yang dapat meningkatkan kemampuan literasi statistis ini.

\section{Daftar Pustaka}

Annizar, A. M., Maulyda, M. A., Khairunnisa, G. F., \& Hijriani, L. (2020). Kemampuan Pemecahan Masalah Matematis Siswa dalam Menyelesaikan Soal PISA pada Topik Geometri. Jurnal Elemen, 6(1), 39-55. https://doi.org/10.29408/jel.v6i1.1688

Azwar, S. (2012). Penyusunan Skala Psikologi. In Pustaka Pelajar.

Bhakti, C. P., \& Maryani, I. (2017). Peran LPTK dalam Pengembangan Kompetensi Pedagogik Calon Guru. Jurnal Pendidikan (Teori Dan Praktik). https://doi.org/10.26740/jp.v1n2.p98-106

Carlson, K., and Winquist, J. (2011). Evaluating an active learning approach to teaching introductory statistics: A classroom workbook approach. Journal of Statistics Education, 19(1).

Croft, T., Kouvela, E., \& Martinez, P. M. (2018). This is what you need to be learning: an analysis of messages received by first-year mathematics students during their transition to university. Math Ed Res J, 30(1), 165-183. Https://Doi.Org/10.1007/S13394-017-0226- 2.

Gal. (2004). Statistical literacy: Meanings, components, responsibilities. In J. B. Garfield \& D. Ben-Zvi (Eds.),. The Challenge Ofdeveloping Statistical Literacy, Reasoning and Thinking (Pp. 47-78). Dordrecht: Kluwer.

Gall, M. D., Borg, W. R., \& Gall, J. P. (1996). Educational research: An introduction. Longman Publishing.

Gundlach, E., Richards, K. A. R., Nelson, D., \& Levesque-Bristol, C. (2015). A comparison of student attitudes, statistical reasoning, performance, and perceptions for web-augmented traditional, fully online, and flipped sections of a statistical literacy class. Journal of Statistics Education, 23(1). https://doi.org/10.1080/10691898.2015.11889723

Hafiyusholeh, M., Budayasa, K., \& Siswono, T. Y. E. (2017). Literasi statistik: Siswa SMA dalam membaca, menafsirkan, dan menyimpulkan Data. Prosiding SI MaNIs (Seminar Nasional Integrasi Matematika Dan Nilai Isami), 1(1), 79-85. http://conferences.uinmalang.ac.id/index.php/SIMANIS/article/view/41

Hariyanti, F. (2020). Statistical Literacy Siswa SMP dalam Pembelajaran Matematika. Ekspose: Jurnal Penelitian Hukum Dan Pendidikan. https://doi.org/10.30863/ekspose.v18i2.564

Khaerunnisa, E., \& Pamungkas, A. S. (2017). Profil Kemampuan Literasi Statistis Mahasiswa Jurusan Pendidikan Matematika Universitas Sultan Ageng Tirtayasa. AKSIOMA: Jurnal Program Studi Pendidikan Matematika. https://doi.org/10.24127/ajpm.v6i2.970 


\section{Range: Jurnal Pendidikan Matematika Vol. 3 No. 1 Tahun 2021 Iyam Maryati}

Maryati, I., Priatna, N., \& Martadiputra, B. A. P. (2019). Analysis of madrasah Tsanawiyah students for statistical literacy abilities. Journal of Physics: Conference Series, 1280(4). https://doi.org/10.1088/1742-6596/1280/4/042016

Maryati, Iyam. (2019). Peningkatan Kemampuan Literasi Statistis, Penalaran Statistis, dan Disposisi Statistis Siswa Madrasah Tsanawiyah Melalui Pembelajaran Berbasis Proyek Modifikasi. Disertasi, UPI Bandung.

Miles, M. B., \& Huberman, A. M. (1994). Qualitative data analysis: An expanded sourcebook. Sage.

Murod, R. R., Priatna, N., \& Martadiputra, B. A. P. (2019). The Scaffolding Approach to Enhance Senior High School Student's Statistical Literacy Ability. Journal of Physics: Conference Series, 1227(1). https://doi.org/10.1088/1742-6596/1227/1/012028

Nahdi, D. S., Araniri, N., Jatisunda, M. G., Kurino, Y. D., \& ... (2021). Statistical Literacy of Pre-Service Islamic Religious Education Teachers. Jurnal Cendekia: Jurnal ..., 05(02), 900-908. https://jcup.org/index.php/cendekia/article/view/494

Nilasari, N. T., \& Anggreini, D. (2019). Kemampuan Literasi Matematika Siswa dalam Menyelesaikan Soal PISA Ditinjau dari Adversity Quotient. Jurnal Elemen, 5(2), 206. https://doi.org/10.29408/jel.v5i2.1342

Pierce, R., \& Chick, H. L. (2013). Workplace statistical literacy: Teachers interpreting box plots. Mathematics Education Research Journal, 25, 189-205.

Pulungan, D. A., \& Herosian, M. Y. (2019). Pengembangan Instrumen Tes Tingkat Literasi Statistis Siswa. SUPERMAT (JURNAL PENDIDIKAN MATEMATIKA). https://doi.org/10.33627/sm.v3i2.259

Ruhyana. (2016). Analisis kesulitan siswa dalam belajar statistik khususnya pada histogram. Jurnal Computech \& Bisnis, 10(2), 106-118.

Sari, R. H. N. (2015). Literasi Matematika: Apa, Mengapa dan Bagaimana? Seminar Nasional Matematika Dan Pendidikan Matematika Uny 2015, 713-720.

Sharma, S. (2017). Definitions and models of statistical literacy: a literature review. Open Review of Educational Research, 4(1), 118-133. https://doi.org/10.1080/23265507.2017.1354313

Takaria, J., \& Talakua, M. (2018a). Kemampuan Literasi Statistik Mahasiswa Calon Guru Ditinjau Dari Kemampuan Awal Matematika. Jurnal Kependidikan.

Takaria, J., \& Talakua, M. (2018b). The Ability of Statistical Literacy Student Teacher Candidate in Terms of Prior-Ability on Mathematics. Jurnal Kependidikan: Penelitian Inovasi Pembelajaran. https://doi.org/10.21831/jk.v2i2.18768

Tiro, M. A. (2018). Strategi Aksi Gerakan Nasional Literasi Statistika di Indonesia. Seminar Nasional Variansi (Venue Artikulasi-Riset, Inovasi, Resonansi-Teori, Dan Aplikasi Statistika).

Widodo, S. A., Ibrahim, I., Hidayat, W., Maarif, S., \& Sulistyowati, F. (2021). Development of Mathematical Problem Solving Tests on Geometry for Junior High School Students. Jurnal Elemen, 7(1), 221-231. https://doi.org/10.29408/jel.v7i1.2973 